\title{
AN ADVANCED MULTI-CRITERIA EVALUATION MODEL OF THE RATIONAL BUILDING ENERGY PERFORMANCE
}

\author{
Darius MIGILINSKAS ${ }^{\mathrm{a}}$, Evaldas BALIONIS ${ }^{\mathrm{a}}$, Rasa DZIUGAITE-TUMENIENE ${ }^{\mathrm{b}}$, \\ Giedrius SIUPSINSKAS ${ }^{\mathrm{b}}$ \\ ${ }^{a}$ Department of Construction Technology and Management, Faculty of Civil Engineering, \\ Vilnius Gediminas Technical University, Sauletekio al. 11, LT-10223 Vilnius, Lithuania \\ ${ }^{b}$ Department of Building Energetics, Faculty of Environmental Engineering, \\ Vilnius Gediminas Technical University, Sauletekio al. 11, LT-10223 Vilnius, Lithuania
}

Received 20 January 2016; accepted 23 May 2016

\begin{abstract}
Different optimization methods generate a large variety of solutions that are suitable for achieving the sets of chosen objectives. The selection of appropriate design variables and objective functions are essential elements in the optimization process. However, the existing methodologies seem to be too complicated and designers seek to use simplified methods in order to evaluate the overall performance of the buildings. The advancement of information technology enables the use of Building Information Modelling and energy simulation tools for the integrated building design in an early stage. Thus, this article introduces a new evaluation method for analysis of the effective solution of the building performance and aims at determining the influence of a complex criteria (construction duration, construction cost, annual bill-based costs, annual primary energy demand, annual $\mathrm{CO}_{2}$ emissions of energy use, $\mathrm{CO}_{2}$ emissions of construction materials and works, thermal comfort) for the final decision making. The findings of the article have confirmed that the high level of the building energy efficiency is not directly proportional to the overall investments, i.e. additional investments do not bring benefits from economic and environmental points of view.
\end{abstract}

Keywords: Building Information Modelling, energy simulation, multi-criteria evaluation.

\section{Introduction}

The global community and politicians pay great attention to the global energy resources that are used to create an indoor climate in a building sector (United Nations 1998; Sillmann et al. 2013). For this reason, nowadays the implementation of targets of an efficient energy use in buildings is the main issue (Mauro et al. 2015; Motuziene et al. 2015). A wide variety of energy performance evaluation methods for buildings are created and applied in the scientific studies and practice in order to increase the energy savings (Henriques et al. 2015), the use of renewable energy technologies (Bernal-Agustín, DufoLópez 2009) and to reduce the $\mathrm{CO}_{2}$ emissions (Diakaki et al. 2013). However, a large number of building design alternatives (Machairas et al. 2014), including passive (low values of heat transfer coefficients of building envelope, high tightness, solar protection systems) and active (high efficiency energy supply systems and technical systems, heat recovery systems, integrated renewable energy technologies) energy efficiency measures, cause a complicated evaluation task in the early design stage and especially analysis for whole life cycle (Dufo-López et al. 2011; Evins 2013).
The overview of the recent scientific researches (Attia et al. 2013; Stevanovic 2013; Nguyen et al. 2014) has shown that the best possible decisions satisfy some combinations of these objectives: energy, technical, ecological, economic, comfort and performance. The complex evaluation of these goals has not been performed yet.

Various researchers analyse revolution of information management in construction industry and in certain case studies there are solutions compatible with the latest research and development topics such as Building Information Modelling (BIM) (Bryde et al. 2013; Sun et al. 2015). The use of BIM methodology globally reaches the highest level of knowledge adoption (Miettinen, Paavola 2014; Abanda et al. 2015) but also faces both real benefits and limitations (Laine et al. 2007; Migilinskas et al. 2013). It is very important to analyse the continuous BIM implementation during the whole project life cycle of building and make complete assessment during all phases and with all team participants (AECO - architecture, engineering, construction and operation). The main objects of BIM implementation research are mostly related with application to newly planned/designed/constructed/maintained buildings and only small majority are suggested

Corresponding author: Darius Migilinskas

E-mail: darius.migilinskas@vgtu.lt 
for the refurbishment projects (Popov et al. 2010; Volk et al. 2014). The sustainability aspects (Kim et al. 2015), development of cost/energy effective and sustainable construction (McArthur 2015; Cemesova et al. 2015) need to be taken into consideration in order to make a suitable project solution.

The rational solutions are derived from the parametric analysis which is performed by modelling tools, multi-criteria decision making methods and multi-objective optimization algorithms, such as genetic, evolutionary, particle swarm optimization (Mohamed et al. 2014; Hamdy et al. 2016). The review of these sources shows that different optimization methods produce a large variety of solutions (Magnier, Haghighat 2010), suitable for achieving the sets of the chosen objectives. Therefore, the selection of appropriate design variables and objective functions are essential elements in the optimization process. However, the existing methodologies seem to be too complicated and the designers seek to use simplified methods in order to evaluate the energy performance of the buildings. Therefore, the advancement of information technology enables a more frequent use of BIM (Building Information Modelling) and energy simulation tools for the integrated building design in an early stage (Kulahcioglu et al. 2012; Sun et al. 2015). BIM application has gained in popularity due to a number of advantages, such as possibility to simulate buildings and processes which are required in order to achieve the result before they actually take place (Popov et al. 2010; Wong et al. 2013; Chen, Luo 2014). At the earliest stage of the life cycle of the building, more efficient collaboration between project participants, a continuous use of information introduced into the model (subsequent use during the operating stage) and better management are required (Laine et al. 2007). In other words, all the tools: BIM, GIS (Geographical Information System), building energy simulation (Mauro et al. 2015) and sustainable development should be combined into the overall system and used throughout the building lifecycle (Motuziene et al. 2015). In terms of energy consumption, information modelling data is fed into the simulator/analyser for more detailed analysis of the energy in order to increase energy efficiency and reduce greenhouse gas emissions (Wong, Fan 2013; Cemesova et al. 2015).

In most of the scientific articles the BIM implementation is described by using certain software, tools and techniques (Popov et al. 2010; Miettinen, Paavola 2014 ) in order to manage various numbers of dimensions, like 2D, 3D, 4D, 5D, and so on (Migilinskas et al. 2013; Abanda et al. 2015; Sun et al. 2015). But finally, all the dimensions are described between the distributed quantative (Žèkas et al. 2014) and qualitative parameters. Quantative parameters are limited to three dimensional geometry in space and time for certain analysis of the three dimensional elements status. From this perspective, quantative parameters are limited to $3 \mathrm{D}$ and $4 \mathrm{D}$ dimensions. For other information (parameters/attributes) deliv- ery qualitative parameters must be used and are mostly used to describe the cost related parameters (Smith 2014; $\mathrm{Lu}$ et al. 2016). The scientists analyse 6D, 7D, 8D and other dimensions in order to reflect sustainability, energy efficiency, maintenance, safety and other aspects, but it is really possible to convert this information and indicators with cost related parameters (Migilinskas et al. 2013; Fazli et al. 2014; Smith 2014; Henriques et al. 2015). It is suggestible to fulfill description of BIM methodology implementation as it is the best technique to ensure the project quality, limited with 5D or 6D dimensions, and the whole project life cycle information management (Chen, Luo 2014; Wang et al. 2014; Lu et al. 2016).

Thus, this study introduces the simplified method for the evaluation of the effective solution of the building performance and aims at determining the influence of a complex set of criteria (construction duration, construction cost, annual bill-based costs, annual primary energy demand, annual $\mathrm{CO}_{2}$ emissions of energy use, $\mathrm{CO}_{2}$ emissions of construction materials and works, thermal comfort) for the final decision making and organised as follows. Section 1 presents input data and muticriteria evaluation model. Section 2 covers methodology for evaluation of the rational building energy performance. Section 3 presents the calculation of criteria weights and multi-criteria method ARAS. Section 4 presents the description of analysed building. Section 5 presents the values of initial indicators. Section 6 presents the results after multi-criteria evaluation with method ARAS. At the end of the article conclusions are presented.

\section{Receiving input data for a multi-criteria evaluation model}

A three-dimensional model of the building can be placed on the world map with regard to the countries of the world using GIS coordination systems. With the help of computer-aided design (CAD) tools, the building model is related with the global coordinates and rotated in the directions of the countries of the world. The analysis of overall building-related information can provide the actual situation of a virtual building with relation to the countries of the world, climate zones and changing seasons. Furthermore, by using the energy simulation tools it is possible to assess energy needs and costs for heating, ventilation and cooling systems.

Using BIM concept and technologies, all the information of the building from architectural geometric models can be easily transferred into the energy simulation (BES) tools, which can simulate almost all complex physical phenomena taking place in the building envelope, internal premises and technical systems. The building energy simulation, performed at the early design stage, enables to select effective design solutions out of possible alternatives. In the design stage BIM technologies include all information about the integrated engineering systems, solar control measures and etc. in one 
place. In this way, the risk of mistakes or discrepancies is reduced. Software cannot replace professionals but it can minimize the risk of errors. Moreover, BIM promotes collaboration between all participants in the construction process to avoid major mistakes and unresolved issues.

In order to implement the simplified method for the evaluation of the effective solution for building performance, this paper presents the integrated use of BIM technologies (Bentley AECOsim, Autodesk Revit \& MEP), the energy simulation software DesignBuilder and the multi-criteria evaluation model. Four models of a multi-storey office building are generated using BIM technologies. Having taken into account the goals of the European Union and the Directive, Lithuania introduced them in its legal framework and added to the building energy performance certificate. Based on the standards of national level, modelling of the possible options (models) of a reference building have been defined and evaluated. Model $A_{1}$ is created according to the technical project, prepared in 2008 (energy efficiency class - C). Model $A_{2}$ satisfies the requirements for the energy efficiency class $\mathrm{B}$. Model $A_{3}$ is generated according to the design project, prepared in 2013 (energy efficiency class - A). Model $A_{4}$ is modelled according to the current situation "as built" (energy efficiency class $-\mathrm{A}_{\text {actual }}$ ). The models of building constructions are made by using Bentley software. The analytical model was created in Revit MEP, in order to get a green building XML (gbXML) format of the model. The gbXML data was loaded to DesignBuilder software for the building energy simulations.

\section{Evaluation of the rational building energy performance}

In this paper the simplified method for the evaluation of the effective solution for the building performance is presented. The method aims at obtaining the effective solution of building performance in terms of construction cost, annual bill-based costs, annual primary energy demand, construction duration, and annual $\mathrm{CO}_{2}$ emissions of energy use, $\mathrm{CO}_{2}$ emissions of construction materials and works, and thermal comfort. The multi-criteria evaluation model of the effective building performance is provided in Figure 1.

A description of evaluation criteria, multi-criteria decision making method ARAS and the assessment of weights of selected criteria are presented below:

- Construction duration $\left(x_{1}\right)$. In order to quantify $\mathrm{CO}_{2}$ emissions due to the working mechanisms in construction stage, the construction duration is evaluated. The criterion is expressed in months.

- Construction cost $\left(x_{2}\right)$. There are evaluating building structure installation cost (evaluating quantity of used concrete), cladding facade installation cost (evaluating quantity of used rock wool), glassed facade installation cost (evaluating quantity of used glasses), roof installation cost (evaluating quantity of used rock wool), and engineering systems instal-

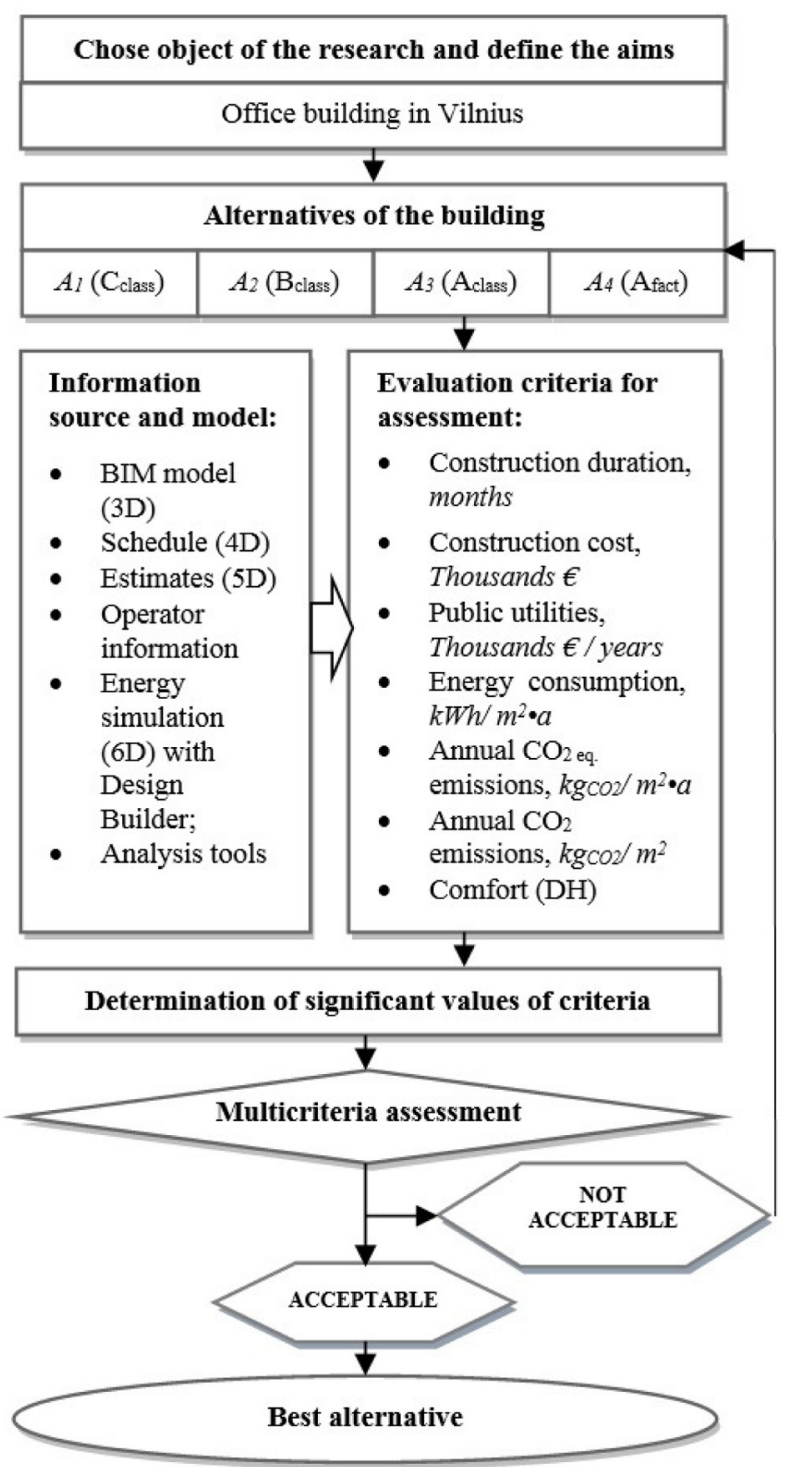

Fig. 1. Multi-criteria evaluation model of the effective building performance

lation cost (evaluating just systems, which create energy efficiency and comfort). Price level 2013.10. The criterion is expressed in thousands of EUR.

- Annual bill-based costs $\left(x_{3}\right)$. There are evaluating public utilities such as electricity, heat energy costs, rental fee, maintenance costs and etc., which are likely to be paid during 5 years exploitation period (price level 2015.10). The quantity of water consumption in these calculations is not evaluated, because it is assumed that water consumption does not depend on the energy efficiency class. The criterion is expressed in thousands of EUR.

- Annual primary energy demand $\left(x_{4}\right)$. Electricity and heat consumptions in calculations are determined for 5 years period and expressed in $\mathrm{kWh} / \mathrm{m}^{2}$.

- Annual $\mathrm{CO}_{2}$ emissions of energy use $\left(x_{5}\right)$. The amount of annual $\mathrm{CO}_{2}$ emissions is used as the ecological criterion. 
- $\mathrm{CO}_{2}$ emissions of construction materials and works $\left(x_{6}\right)$. The quantity of $\mathrm{CO}_{2}$ emissions are determined for the used concrete production and transportation, used in facade glasses production and transportation, used insulation materials (rock wool) production and transportation and for tower crane work, because according to the research, in high-rise building construction stage a tower crane work produces the biggest part of $\mathrm{CO}_{2}$ emissions of all mechanisms (Wong et al. 2013; Štreimikienè 2013).

- Thermal Comfort $\left(x_{7}\right)$. The number of discomfort hours (DH) during the whole year is used as thermal comfort criteria.

\section{Calculation of criteria weights and multi-criteria method ARAS}

The weights of each criterion $\left(w_{1}, w_{2}, w_{3}, w_{4}, w_{5}, w_{6}\right.$, $w_{7}$ ) have been determined by using the expert assessment method. The experts filled in 20 questionnaires in order to calculate the weight of each criterion according to the rating scale. The criteria weights $\left(w_{j}\right)$ have been calculated using the AHP (Ertay et al. 2013; Kutut et al. 2014). Following the results of the questionnaires and the pairwise comparison method, the determined criteria weights are presented in Table 1.

Table 1. The pair-wise comparison of criteria weights $\left(w_{1}, w_{2}\right.$, $\left.w_{3}, w_{4}, w_{5}, w_{6}, w_{7}\right)$

\begin{tabular}{|c|c|c|c|c|c|c|c|c|c|}
\hline & $x_{1}$ & $x_{2}$ & $x_{3}$ & $x_{4}$ & $x_{5}$ & $x_{6}$ & $x_{7}$ & $\Sigma$ & $w_{i}$ \\
\hline$x_{1}$ & & 0.5 & 1.0 & 0.5 & 1.0 & 1.0 & 0.5 & 4.5 & 0.080 \\
\hline$x_{2}$ & 2.0 & & 6 & 3 & 5 & 1 & 1 & 18.0 & 0.310 \\
\hline$x_{3}$ & 1.0 & 0.2 & & 1 & 1 & 1 & 1 & 5.2 & 0.094 \\
\hline$x_{4}$ & 2.0 & 0.3 & 1.0 & & 5 & 3 & 1 & 12.3 & 0.207 \\
\hline$x_{5}$ & 1.0 & 0.2 & 1.0 & 0.2 & & 2 & 1 & 5.4 & 0.100 \\
\hline$x_{6}$ & 1.0 & 1.0 & 1.0 & 0.3 & 0.5 & & 2 & 5.8 & 0.100 \\
\hline$x_{7}$ & 2.0 & 1.0 & 1.0 & 1.0 & 1.0 & 0.5 & & 6.5 & 0.110 \\
\hline
\end{tabular}

The opinions of experts are concerted. The coefficient of compatibility, when the number of liberty degree is 4 and the level of reliability is $0.01 \%$. After the calculation of criteria weights, the initial decision making matrix has been formed for the further multi-criteria evaluation using method ARAS.

In order to determine the best alternative, calculations have been made using method ARAS. The multicriteria decision making method Additive Ratio ASsessment (ARAS) is used for the final decision making in the rank of the design variants of the building (Zavadskas, Turskis 2010; Kutut et al. 2014). The calculations include the following 4 models: $A_{1}\left(\mathrm{C}_{\text {calc }}\right), A_{2}\left(\mathrm{~B}_{\text {calc }}\right), A_{3}\left(\mathrm{~A}_{\text {calc }}\right)$, $A_{4}\left(\mathrm{~A}_{\text {actual }}\right)$, which are based on the initial values of criteria and $A_{0}$ - optimal values. The relative significances of criteria (criteria weights) $w_{j}$ are determined accord- ing to the survey that involved 20 construction-related experts. In this article all the selected criteria are minimized. Therefore, the criteria, the preferable values of which are minimal, are normalized by applying a twostage procedure:

$$
x_{i j}=\frac{1}{x_{i j}^{*}} ; \quad \bar{x}_{i j}=\frac{x_{i j}}{\sum_{i=0}^{m} x_{i j}} .
$$

The sum of weights $w_{j}$ must be limited to the requirement:

$$
\sum_{j=1}^{n} w_{j}=1
$$

Normalized-weighted values of all the criteria are calculated as follows:

$$
\hat{x}_{i j}=\bar{x}_{i j} w_{j} ; \quad i=\overline{0, m}
$$

where $w_{j}$ is the weight (importance) of criterion $\mathrm{j}$ and $\bar{x}_{i j}$ is the normalized rating of criterion $j$.

The following task is to determine values of optimality function:

$$
S_{i}=\sum_{j=1}^{n} \hat{x}_{i j} ; \quad i=\overline{0, m}
$$

where $S_{i}$ is the value of optimality function of alternative $i$.

\section{Description of analysed building}

The selected analysis object for the case study is a multistorey office building, located in Vilnius (Lithuania). The total floor area of the building is $9560 \mathrm{~m}^{2}$ and the building has 21 floors. The models of the reference building are shown in Figure 2 (Kulahcioglu et al. 2012).

The reduction of greenhouse gas emissions is an integral part of the energy performance. Considering the goals of the European Union, Lithuania has introduced the regulation of "Design of Energy Performance of Buildings", presenting all the requirements for different energy performance class. The regulation is implemented in accordance with the Directive 2010/31/EU of the European Parliament (2010). The heat transfer coefficients (U-values) used in analysis are based on the regulations and used for the building envelope elements according to the energy classes.

The energy simulation software DesignBuilder is used for three models $\left(A_{1}, A_{2}, A_{3}\right)$. The results of the energy simulation of three different models of the building show that the energy demand for heating is reduced by $74.3 \%$ in the case of model $A_{3}$ compared with the results of model $A_{1}$. The energy demand for cooling reduces only by $8 \%$. Therefore, in the case of energy efficiency class $\mathrm{A}$, the annual primary energy demand and the amount of $\mathrm{CO}_{2}$ emissions are lower 

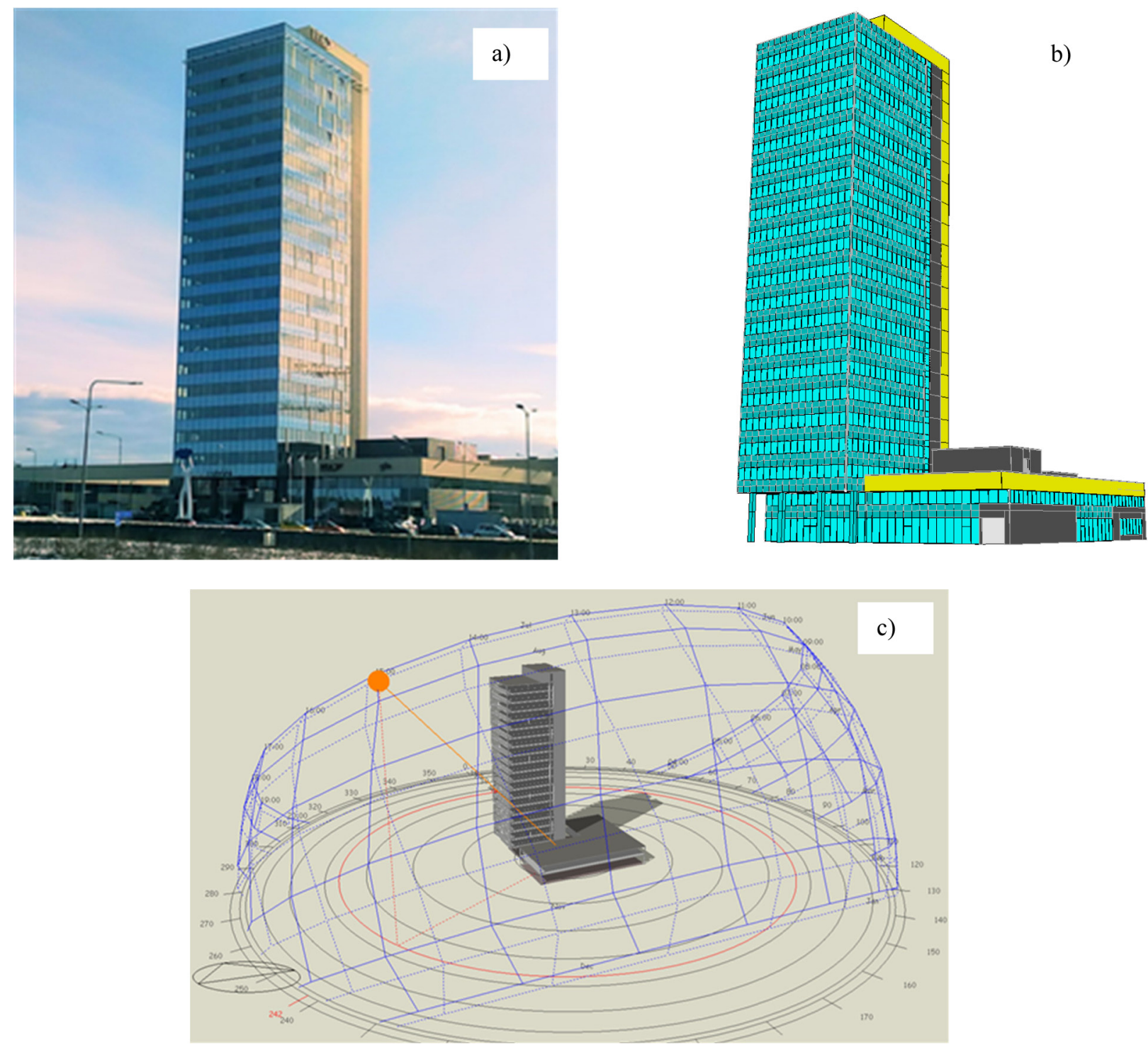

Fig. 2. The office building: a) an actual image, b) 3D model, c) energy simulation model

by $10 \%$ comparing with the design variant of class $\mathrm{B}$; and lower by $14.6 \%$ in comparison with the variant of class $\mathrm{C}$.

Following the simulation results of the models of the building, due to higher requirements for building tightness and thermal characteristics, the discomfort hours increase in the case of model $A_{3}$. The building is overheating thereby causing discomfort of occupancy. The additional solar control measures, which shall further raise the construction cost, must be implemented. For the evaluation of building models, the same thermal comfort level of model $A_{3}$ is foreseen for model $A_{4}$, because any measurements of microclimate parameters are not performed on site.

\section{Values of initial indicators}

The values of the initial indicators collected from building information models, energy simulations, intermediate calculations, analysis reports and assumptions for the multi-criteria evaluation of the rational building energy performance are presented in Table 2.

\section{Results after multi-criteria evaluation with ARAS}

The biggest value is the best, and the least one is the worst. A weighted-normalized decision making matrix for method ARAS with final results is presented in Table 3 . The results show that a priority sequence of the models is as follows: $A_{2}>A_{1}>A_{3}>A_{4}$. Therefore, considering the selected four models of the multi-storey office building, the best solution is alternative $A_{2}$.

Comparing quantities of sub-criteria of construction cost between building alternatives A (prepared according the design project) and $\mathrm{A}_{\text {actual }}$ (created by modelling, according the current situation), we can see that both of them are increased and that probably they are the reason of the construction cost increase. It could also be impacted by the increasing construction duration and it is very important for the evaluation of $\mathrm{CO}_{2}$ emissions, which, 
Table 2. Initial indicators for building performance evaluation according to the energy efficiency classes

\begin{tabular}{l|c|c|c|c|c}
\hline \multirow{2}{*}{ Evaluation criteria } & \multirow{2}{*}{ Units } & \multicolumn{4}{c}{ Energy efficiency class / Values } \\
\cline { 3 - 6 } & & $\mathrm{C}$ & $\mathrm{B}$ & $\mathrm{A}$ & $\mathrm{A}_{\text {actual }}$ \\
\hline Construction duration & months & 10.50 & 10.90 & 12.10 & 13.60 \\
\hline Construction cost & Thousands $€$ & 3846.6 & 3831.7 & 4618.8 & 4656.8 \\
\hline Annual bill-based costs & Thousands $€ / a$ & 1131.7 & 1250.9 & 1529.5 & 1594.4 \\
\hline Annual primary energy & $\mathrm{kWh} / \mathrm{m}^{2} \cdot a$ & 245.5 & 224.6 & 205.4 & 214.0 \\
\hline Annual $\mathrm{CO}_{2}$ emissions of energy use & $\mathrm{kg}_{\mathrm{CO} 2} / \mathrm{m}^{2} \cdot \mathrm{a}$ & 51.7 & 49.0 & 44.1 & 46.3 \\
\hline $\mathrm{CO}_{2}$ emissions of construction materials and works & $\mathrm{kg}_{\mathrm{CO} 2} / \mathrm{m}^{2}$ & 3652.6 & 3684.5 & 3771.3 & 3650.6 \\
\hline Thermal comfort & $\mathrm{DH}$ & 2020 & 2051 & 2674 & 2674 \\
\hline
\end{tabular}

Table 3. A weighted-normalized decision making matrix for method ARAS with final results

\begin{tabular}{|c|c|c|c|c|c|c|}
\hline \multirow[b]{2}{*}{ Criteria } & \multirow{2}{*}{$\begin{array}{l}\text { Optimization } \\
\text { direction }\end{array}$} & \multicolumn{5}{|c|}{ Models / Results } \\
\hline & & $\begin{array}{c}A_{1} \\
C_{\text {calc. }} \\
\end{array}$ & $\begin{array}{c}A_{2} \\
B_{\text {calc. }} \\
\end{array}$ & $\begin{array}{c}A_{3} \\
A_{\text {calc. }}\end{array}$ & $\begin{array}{c}A_{4} \\
A_{\text {actual }}\end{array}$ & $A_{0}$ \\
\hline Construction duration $\left(x_{1}\right)$ & $\min$ & 0.0173 & 0.0167 & 0.0150 & 0.0134 & 0.0176 \\
\hline Construction cost $\left(x_{2}\right)$ & $\min$ & 0.0663 & 0.0666 & 0.0552 & 0.0548 & 0.0671 \\
\hline Annual bill-based costs $\left(x_{3}\right)$ & $\min$ & 0.0215 & 0.0195 & 0.0159 & 0.0153 & 0.0218 \\
\hline Annual primary energy demand $\left(x_{4}\right)$ & $\min$ & 0.0367 & 0.0401 & 0.0439 & 0.0421 & 0.0442 \\
\hline Annual $\mathrm{CO}_{2}$ emissions of energy use $\left(x_{5}\right)$ & $\min$ & 0.0181 & 0.0191 & 0.0212 & 0.0202 & 0.0215 \\
\hline $\mathrm{CO}_{2}$ emissions of construction materials and works $\left(x_{6}\right)$ & $\min$ & 0.0203 & 0.0202 & 0.0197 & 0.0195 & 0.0203 \\
\hline Thermal comfort $\left(x_{7}\right)$ & $\min$ & 0.0242 & 0.0238 & 0.0183 & 0.0183 & 0.0244 \\
\hline Index of effectiveness $R$ & & 0.2045 & 0.2059 & 0.1892 & 0.1835 & 0.2170 \\
\hline
\end{tabular}

as we see, are also increased. In this case, it reveals one benefit of the three-dimensional modelling - to design buildings and necessary processes to achieve results in advance.

By comparing total quantities of energy consumption between building alternatives $\mathrm{A}$ and $\mathrm{A}_{\text {actual }}$, we can see that in fact, it is 1.5-2 times higher than it has been planned. In this case, the increase of the used energy cost (increased taxes) also increases $\mathrm{CO}_{2}$ emissions. One of the reasons for such increased energy consumption may be that the tenants of the building, for personal reasons, feel comfortable in the workplace at higher than defined in norms values (the amount of air, room temperature, etc.), what causes the increase of energy consumption.

\section{Conclusions}

The article presents a new approach for the evaluation of the effective solution for building performance, which can be used on an early integrated design stage. The approach is based on the complex set of determined criteria and the integrated use of BIM, the energy simulation software DesignBuilder and the multi-criteria method ARAS.

The analysis of design variants of the multi-storey office building and the assessment of the above mentioned criteria, using various calculation methods have shown that the best alternative is the building of energy efficiency class B (alternative $A_{2}$ ). Therefore, the present article has confirmed the probability that the high level of the building energy efficiency is not (or not always) proportional to the investment, i.e. additional investment does not bring benefits from economic and environmental points of view. Choosing between energy efficiency class $\mathrm{A}$ and class $\mathrm{B}$, the relevant list of economic and environmental criteria need to be analysed. The final decision can be done by assessor understanding the difference or change of criteria values (simulated/calculated class $\mathrm{B}$ comparing with class $\mathrm{A}$ or class $\left.\mathrm{A}_{\text {actual }}\right)$ :

- Construction duration $\left(x_{1}\right)$ can increase by 9.9-19.9\%;

- Construction cost $\left(x_{2}\right)$ can increase by $17.0-17.7 \%$;

- Annual bill-based costs $\left(x_{3}\right)$ can increase by 18.2-21.5\%;

- Annual primary energy demand $\left(x_{4}\right)$ can decrease by $5.0-9.4 \%$;

- Annual $\mathrm{CO}_{2}$ emissions of energy use $\left(x_{5}\right)$ can decrease by $5.8-11.1 \%$;

- $\mathrm{CO}_{2}$ emissions of construction materials and works $\left(x_{6}\right)$ can increase by $2.3-3.4 \%$;

- Thermal comfort $\left(x_{7}\right)$ decreases by $23.3 \%$.

In the future, the proposed model will be supplemented with a cost-optimality analysis, including a life cycle assessment (LCA) and life cycle cost analysis (LCC). 


\section{Acknowledgements}

The authors would like to acknowledge the Laboratory of Building and Microclimate Systems and Technology Centre for Building Information and Digital Modelling of Vilnius Gediminas Technical University.

\section{References}

Abanda, F. H.; Vidalakis, C.; Oti, A. H.; Tah, J. H. M. 2015. A critical analysis of Building Information Modelling systems used in construction projects, Advances in Engineering Software 90: 183-201. http://dx.doi.org/10.1016/j.advengsoft.2015.08.009

Attia, S.; Hamdy, M.; O’Brien, W.; Carlucci, S. 2013. Assessing gaps and needs for integrating building performance optimization tools in net zero energy buildings design, Energy and Buildings 60: 110-124.

http://dx.doi.org/10.1016/j.enbuild.2013.01.016

Bernal-Agustín, J. L.; Dufo-López, R. 2009. Efficient design of hybrid renewable energy systems using evolutionary algorithms, Energy Conversion and Management 50(3): 479489. http://dx.doi.org/10.1016/j.enconman.2008.11.007

Bryde, D.; Broquetas, M.; Volm, J. M. 2013. The project benefits of Building Information Modelling (BIM), International Journal of Project Management 31(7): 971-980. http://dx.doi.org/10.1016/j.ijproman.2012.12.001

Cemesova, A.; Hopfe, J. C.; Mcleod, R. S. 2015. PassivBIM: enhancing interoperability between BIM and low energy design software, Automation in Construction 57: 17-32. http://dx.doi.org/10.1016/j.autcon.2015.04.014

Chen, L. J.; Luo, H. A. 2014. BIM-based construction quality management model and its applications, Automation in Construction 46: 64-73.

http://dx.doi.org/10.1016/j.autcon.2014.05.009

Diakaki, C.; Grigoroudis, E.; Kolokotsa, D. 2013. Performance study of a multi-objective mathematical programming modelling approach for energy decision-making in buildings, Energy 59: 534-542. http://dx.doi.org/10.1016/j.energy.2013.07.034

Dufo-López, R.; Bernal-Agustín, J. L.; Yusta-Loyo, J. M.; Domínguez-Navarro, J. A.; Ramírez-Rosado, I. J.; Lujano, J.; Aso, I. 2011. Multi-objective optimization minimizing cost and life cycle emissions of stand-alone PV-winddiesel systems with batteries storage, Applied Energy 88(11): 4033-4041. http://dx.doi.org/10.1016/j.apenergy.2011.04.019

Ertay, T.; Kahraman, C.; Kaya, I. 2013. Evaluation of renewable energy alternatives using MACBETH and fuzzy AHP multicriteria methods: the case of Turkey, Technological and Economic Development of Economy 19(1): 38-62. http://dx.doi.org/10.3846/20294913.2012.762950

European Parliament. 2010. Directive 2010/31/EU of the European Parliament and of the Council of 19 May 2010 on the energy performance of buildings, Official Journal of the European Union 53: 13-35. http:dx.doi.org/10.3000/17252555.L_2010.153.eng

Evins, R. 2013. A review of computational optimisation methods applied to sustainable building design, Renewable and Sustainable Energy Reviews 22: 230-245. http://dx.doi.org/10.1016/j.rser.2013.02.004

Fazli, A.; Fathi, S.; Enferadi, M. H.; Fazli, M.; Fathi, B. 2014. Appraising effectiveness of Building Information Management (BIM) in project management, Procedia Technology 16: 1116-1125. http://dx.doi.org/10.1016/j.protcy.2014.10.126

Hamdy, M.; Nguyen, A. T.; Hensen, J. L. M. 2016. A performance comparison of multi-objective optimization al- gorithms for solving nearly-zero-energy-building design problems, Energy and Buildings 121: 57-71.

http://dx.doi.org/10.1016/j.enbuild.2016.03.035

Henriques, C. O.; Coelho, D. H.; Antunes, C. H. 2015. A multi-objective input-output model to assess E4 impacts of building retrofitting measures to improve energy efficiency, Technological and Economic Development of Economy 21(3): 483-494. http://dx.doi.org/10.3846/20294913.2015.1015065

Kim, J. I.; Kim, J.; Fischer, M.; Orr, R. 2015. BIM-based decision-support method for master planning of sustainable large-scale developments, Automation in Construction 58: 95-108. http://dx.doi.org/10.1016/j.autcon.2015.07.003

Kulahcioglu, T.; Dang, J.; Toklu, C. 2012. A 3D analyzer for BIM-enabled Life Cycle Assessment of the whole process of construction, HVAC\&R Research 18(1-2): 283-293.

Kutut, V.; Zavadskas, E. K.; Lazauskas, M. 2014. Assessment of priority alternatives for preservation of historic buildings using model based on ARAS and AHP methods, Archives of Civil and Mechanical Engineering 14(2): 287-294. http://dx.doi.org/10.1016/j.acme.2013.10.007

Laine, T.; Hänninen, R.; Karola, A. 2007. Benefits of bim in the thermal performance menagement, in Building Simulation Conference Proceedings, 3-6 September 2007, Beijing, China, 1455-1461.

Lu, Q.; Won, J.; Cheng, J. C. P. 2016. A financial decision making framework for construction projects based on 5D Building Information Modeling (BIM), International Journal of Project Management 34(1): 3-21. http://dx.doi.org/10.1016/j.ijproman.2015.09.004

Machairas, V.; Tsangrassoulis, A.; Axarli, K. 2014. Algorithms for optimization of building design: a review, Renewable and Sustainable Energy Reviews 31(1364): 101-112. http://dx.doi.org/10.1016/j.rser.2013.11.036

Magnier, L.; Haghighat, F. 2010. Multiobjective optimization of building design using TRNSYS simulations, genetic algorithm, and Artificial Neural Network, Building and Environment 45(3): 739-746.

http://dx.doi.org/10.1016/j.buildenv.2009.08.016

Mauro, G. M.; Hamdy, M.; Vanoli, G. P.; Bianco, N.; Hensen, J. L. M. 2015. A new methodology for investigating the cost-optimality of energy retrofitting a building category, Energy and Buildings 107: 456-478. http://dx.doi.org/10.1016/j.enbuild.2015.08.044

McArthur, J. J. 2015. A Building Information Management (BIM) framework and supporting case study for existing building operations, maintenance and sustainability, Procedia Engineering 118: 1104-1111. http://dx.doi.org/10.1016/j.proeng.2015.08.450

Miettinen, R.; Paavola, S. 2014. Beyond the BIM utopia: approaches to the development and implementation of building information modeling, Automation in Construction 43: 84-91. http://dx.doi.org/10.1016/j.autcon.2014.03.009

Migilinskas, D.; Popov, V.; Juocevicius, V.; Ustinovichius, L. 2013. The benefits, obstacles and problems of practical BIM implementation, Procedia Engineering 57: 767-774. http://dx.doi.org/10.1016/j.proeng.2013.04.097

Mohamed, A.; Hasan, A.; Sirén, K. 2014. Fulfillment of netzero energy building (NZEB) with four metrics in a single family house with different heating alternatives, Applied Energy 114: 385-399. http://dx.doi.org/10.1016/j.apenergy.2013.09.065

Motuzienè, V.; Rogoža, A.; Lapinskienè, V.; Vilutienė, T. 2015. Construction solutions for energy efficient single-family house based on its life cycle multi-criteria analysis: a case study, Journal of Cleaner Production 112: 532-541. http://dx.doi.org/10.1016/j.jclepro.2015.08.103

Nguyen, A. T.; Reiter, S.; Rigo, P. 2014. A review on simulation-based optimization methods applied to building per- 
formance analysis, Applied Energy 113: 1043-1058. http://dx.doi.org/10.1016/j.apenergy.2013.08.061

Smith, P. 2014. BIM and the 5D project cost manager, Procedia - Social and Behavioral Sciences 119(19): 475-484. http://dx.doi.org/10.1016/j.sbspro.2014.03.053

Popov, V.; Juocevicius, V.; Migilinskas, D.; Ustinovichius, L.; Mikalauskas, S. 2010. The use of a virtual building design and construction model for developing an effective project concept in 5D environment, Automation in Construction 19: $357-367$.

http://dx.doi.org/10.1016/j.autcon.2009.12.005

Sillmann, J.; Kharin, V. V.; Zwiers, F. W.; Zhang, X.; Bronaugh, D. 2013. Climate extremes indices in the CMIP5 multimodel ensemble: part 2. Future climate projections, Journal of Geophysical Research Atmospheres 118(6): 2473-2493. http://dx.doi.org/10.1002/jgrd.50188

Stevanovic, S. 2013. Optimization of passive solar design strategies: a review, Renewable and Sustainable Energy Reviews 25: 177-196. http://dx.doi.org/10.1016/j.rser.2013.04.028

Sun, C.; Jiang, S.; Skibniewski, M.; Man, Q.; Shen, L. 2015. A literature review of the factors limiting the application of BIM in the construction industry, Technological and Economic Development of Economy (in press). http://dx.doi.org/10.3846/20294913.2015.1087071

Štreimikiené, D. 2013. Assessment of energy technologies in electricity and transport sectors based on carbon intensity and costs, Technological and Economic Development of Economy 19(4): 606-620.

http://dx.doi.org/10.3846/20294913.2013.837113
United Nations. 1998. Kyoto Protocol to the United Nations framework convention on climate change.

Volk, R.; Stengel, J.; Schultmann, F. 2014. Building Information Modeling (BIM) for existing buildings - literature review and future needs, Automation in Construction 38: 109-127. http://dx.doi.org/10.1016/j.autcon.2013.10.023

Wang, X.; Yung, P.; Luo, H.; Truijens, M. 2014. An innovative method for project control in LNG project through 5D CAD: a case study, Automation in Construction 45: 126-135. http://dx.doi.org/10.1016/j.autcon.2014.05.011

Wong, J. K. W.; Li, H.; Wang, H.; Huang, T.; Luo, E.; Li, V. 2013. Toward low-carbon construction processes: the visualisation of predicted emission via virtual prototyping technology, Automation in Construction 33: 72-78. http://dx.doi.org/10.1016/j.autcon.2012.09.014

Wong, K.; Fan, Q. 2013. Building information modelling (BIM) for sustainable building design, Facilities 31(3): 138-157. http://dx.doi.org/10.1108/02632771311299412

Zavadskas, E. K.; Turskis, Z. 2010. A new additive ratio assessment (ARAS) method in multicriteria decision-making, Technological and Economic Development of Economy 16(2): 159-172. http://dx.doi.org/10.3846/tede.2010.10

Žèkas, V.; Martinaitis, V.; Streckienė, G.; Vilutiené, T. 2014. A quantitative evaluation of theoretical renewable energy potential of the building site, Journal of Civil Engineering and Management, 20(6): 873-883. http://dx.doi.org/10.3846/13923730.2014.976589

Darius MIGILINSKAS. Associate professor at Department of Construction Technology and Management, Vilnius Gediminas Technical University. Doctor of Technological Sciences (Civil Engineering 02T) in VGTU, 2010. Publications: the author and co-author of over 40 research papers in international scientific journals and international conferences. Research interests: new technologies and management of construction works; PLM and BIM modelling in Civil Engineering; uncertainty and risk management; game theory in construction's decision making.

Evaldas BALIONIS. MSc student of Construction Technology and Management at Vilnius Gediminas Technical University. Publications: the author and co-author of 3 research papers in scientific journals and international conferences. Research interests: construction technologies, BIM modelling.

Rasa DZIUGAITE-TUMENIENE. Associate professor at Department of Building Energetics, Vilnius Gediminas Technical University. Doctor of Technological Sciences (Civil Engineering 02T) in VGTU, 2015. Publications: the author and co-author of 13 research papers in international scientific journals and international conferences. Research interests: energy efficiency in buildings, integration of renewable energy sources into the energy supply systems, energy simulations.

Giedrius SIUPSINSKAS. Associate professor at Department of Building Energetics, Vilnius Gediminas Technical University. Doctor of Technological Sciences (Energetics and Thermal Engineering 06T) in VGTU, 2007. Publications: the author and co-author of 40 research papers in international scientific journals and international conferences. Research interests: renewable energy technologies, process and system integration, energy supply. 